\title{
MOTIF WANITA RAWAN SOSIAL DAN EKONOMI DALAM KOMUNITAS IKATAN JANDA MUSLIMAH PONOROGO (IJMP)
}

\author{
Yusuf Adam Hilman \\ Program Studi Ilmu Pemerintahan, \\ Universitas Muhammadiyah Ponorogo \\ adamhilman@umpo.ac.id
}

\begin{abstract}
This research was conducted in Ponorogo Regency on the organization of the Ponorogo Muslimah Widow Association (IJMP). To obtain data, this study used interview techniques with purposive sampling technique. The results of this study show that there are 2 (two) models of actions that become the motives of IJMP members, namely: 1) rational actions, and 2) nonrational actions. Rational actions are divided into two, namely, instrumental rational actions, which describe conscious choice, and value-oriented actions, which describe efficiency and effectiveness. Non-rational actions are also divided into two, actions that are related to customs and beliefs, and actions that are dominated by personal feelings. The reason must be a strong woman: to survive and believe in religious teachings. HJMP members have consideration of rational and non-rational actions and in groups they try to maintain their chosen social actions.
\end{abstract}

Keywords: motive, divorce, social action

\begin{abstract}
Penelitian ini dilakukan di Kabupaten Ponorogo pada organisasi Ikatan Janda Muslimah Ponorogo (IJMP). Untuk memperoleh data digunakan teknik wawancara dengan teknik purposive sampling. Hasil penelitian ini didapatkan bahwa ada 2 (dua) model tindakan yang menjadi motif anggota IJMP, yaitu: 1) tindakan rasional, dan 2) tindakan non -rasional. Tindakan rasional dibagi dua yakni, tindakan rasional instrumental, yang menggambarkan pilihan secara sadar, dan tindakan berorientasi nilai, yang menggambarkan efisiensi dan efektifitas. Tindakan non-rasional juga dibagi dua, tindakan yang terkait adat istiadat dan juga keyakinan, dan tindakan yang didominasi perasaan pribadi. Alasan harus menjadi wanita yang kuat: untuk bertahan hidup dan keyakinan terhadap ajaran agama. Anggota HJMP memiliki
\end{abstract}


pertimbangan tindakan rasional dan non-rasional dan dengan berkelompok mereka mencoba mempertahankan tindakan sosial yang mereka pilih.

Keywords: motif, perceraian, aksi sosial

\section{PENDAHULUAN}

\section{Komunitas Ikatan Janda} Muslimah Ponorogo

Posisi wanita dalam kehidupan masyarakat, dari masa ke masa menunjukkan perubahan. Dahulu wanita diposisikan selalu di belakang dan terbelakang, atau di nomor dua kan. Ada beberapa istilah dalam bahasa Jawa yang menyebutkan wanita sebagai "konco wingking". Istilah tersebut merujuk pada posisi wanita yang hanya bisa berlindung di bawah laki-laki. Perlahan-lahan asumsi tersebut kini telah berubah, dimana wanita di posisikan secara sejajar dengan laki-laki. Terdapat kesamaan hak dan kesempatan dalam menjalani kehidupan sehari-hari.

Tika Santika (2012) menjelaskan bahwa posisi wanita sejak dahulu memiliki kedudukan, peran, serta fungsi yang berubah-ubah. Kedudukan wanita perlahan-lahan tapi pasti mampu mengambil peranan yang dahulu lebih didominasi oleh kaum laki-laki, sehingga keberadaan wanita saat ini bisa setara dan berdaya.

Menyoal permasalahan gender, sebenarnya dalam konstitusi di Indonesia sudahdiatursecarajelasbahwa kesetaraan yang diinginkan oleh bangsa Indonesia, yaitu: "Kesamaan kondisi bagi laki-laki dan wanita untuk memperoleh kesempatan dan hak-haknya sebagai manusia agar mampu berperan dan berpartisipasi dalam kegiatan politik, ekonomi, sosial budaya, pertahanan dan kemananan nasional dan kesamaan dalam menikmati hasil pembangunan tersebut" (Inpres No. 9, 2000).

Perjuangan "kaum Hawa" untuk mendapatkan kesetaraan dengan kaum laki-laki dijalankan dalam proses panjang dan penuh liku, mengingat di Indonesia stigma yang berkembang masih sangat kuat bahwa wanita dianggap makhluk lemah. Sejarah telah membuktikan bahwa wanita saat ini memiliki kesempatan yang terbuka untuk menjalankan profesi yang biasanya identik dengan laki-laki, sehingga tidak menjadi masalah apabila kita berbagi peranan dalam kehidupan di masyarakat, karena wanita juga mampu melaksanakannya. Anggota Ikatan Janda Muslimah Ponorogo (IJMP) dengan statusnya yang khas, memang bukan pilihan yang mudah. Banyak stereotype terkait status tersebut, yang berkonotasi negatif sehingga pasti akan lebih berat dalam menjalani kehidupan. Selain itu, beban keluarga pasti akan bertambah karena memikul tanggungjawab sebagai ibu dan bahkan bapak bagi anak-anaknya.

Hasil penelitian ini menunjukkan bahwa sebagian anggota masyarakat kampung Iromejan berpersepsi bahwa janda merupakan orang yang harus lebih dipantau, diperhatikan, dan dijaga karena cenderung riskan, terutama janda yang masih muda. Selain itu, masih ada anggapan umum bahwa janda lebih cenderung dicap atau diberi 
label sebagai perusak hubungan suami istri. Akan tetapi masyarakat setempat masih menanggapi hal tersebut dengan bijak dengan melihat latar belakangnya terlebih dahulu.

Di sisi lain, masyarakat Iromejan menilai bahwa janda pantas diteladani karena ketegaran dan kekuatan mereka dalam melanjutkan hidup tanpa suami. Faktor yang mempengaruhi adanya persepsi tersebut diantaranya adalah usia, jenis kelamin, keadaan janda yang beraneka ragam, baik perasaan, pengalaman, dan sikap mereka sehari-hari; keadaan masyarakat yang mempersepsi, pengalaman bersama kaum janda, serta kondisi lingkungan masyarakat dengan kultur yang guyub rukun dengan hubungan seperti saudara, saling menjaga dan berempati (Karvistina, 2011).

Beberapa penelitian terdahulu yang dapat dihimpun oleh peneliti memperlihatkan bahwa fenomena "janda" banyak memberikan gambaran terkait kenapa memilih menjadi janda dan apa saja faktor yang melandasinya. Millati menjelaskan bahwa di Indonesia masyarakat masih cenderung memberikan citra yang negatif kepada janda. Dengan mudah orang dapat menimpakan macam-macam apa yang menjadi alasan wanita itu menjanda dan semua dugaan mengenai alasan status menjandanya (Millati, 2000). Selanjutnya, strategi bertahan hidup kaum janda dapat dijelaskan yaitu (1) menjadi pribadi terbaik menurut dirinya sendiri; (2) menjaga kedekatan dengan anak, memberikan pengasuhan dan pendidikan terbaik untuk anak; (3) pemanfaatan jaringan sosial (meminta bantuan atau pertolongan kepada orang tua, sanak saudara, tetangga, dan sahabat); (4) bersyukur dengan keadaan ekonomi saat ini (Sutopo, 2015).

Ari Susanti dalam penelitiannya yang berjudul "Aplikasi Tanggung Jawab Nafkah Keluarga Pasca Perceraian: Komparasi Janda Mati dengan Janda Cerai Ditinjau dari Hukum Islam (Studi Kasus di Desa Margolelo Kec. Kandangan, Kab. Temanggung)" menjelaskan bahwa tanggungjawab janda mati dan janda cerai terhadap keluarganya tidak hanya merawat dan mendidik anak-anaknya, namun juga memenuhi kebutuhan sehari-harinya bersama anak dan keluarganya (Ariesta, 2017). Namun, dari beberapa hasil penelitian tersebut masih sedikit sekali pembahasan terkait motif, putusan, atau pilihan menjadi janda. Selama ini hasil kajian masih berkutat pada fenomena kehidupan janda, bukan pada pilihan tindakan atau motif yang dilakukan oleh wanita bersatus "janda".

\section{PENJELASAN KONSEPTUAL}

\section{Janda}

Dalam Kamus Besar Bahasa Indonesia, janda yaitu seorang wanita yang diceraikan atau ditinggal mati oleh suaminya (KBBI, 1997). Ada beberapa hal yang menyebabkan seseorang menjanda, diantaranya: 1) wanita hidup lebih lama daripada pria; 2) wanita umumnya menikahi pria yang lebih tua dari mereka sendiri; 3) lelaki tua lebih mungkin menikah lagi daripada wanita tua; 4) adanya norma sosial yang kuat yang menentang wanita tua menikahi pria muda dan juga norma-norma yang menentang wanita tua menikah lagi. Selain itu, Belski (1997) menambahkan 
bahwa alasan menjanda adalah karena wanita cenderung tidak menikah lagi karena merasa bahwa tidak akan pernah menemukan lagi orang yang sebaik suaminya dulu. Menurut Glaser permasalahan utama yang dihadapi seorang janda adalah kesulitan ekonomi karena keterbatasan pendapatan yang diperolehnya (Glaser, 1999). Secara finansial kematian pasangan selalu menyebabkan kesulitan ekonomi walaupun dalam beberapa kasus istri merupakan ahli waris dari suaminya, namun selalu ada biaya yang harus dikeluarkan misalnya untuk biaya dokter dan pembuatan makam (Kephard, 1991).

\section{MOTIF}

Motif adalah dorongan yang sudah terikat pada suatu tujuan. Motif menunjuk pada hubungan sistematik antara suatu respon dengan keadaan dorongan tertentu. Motif yang ada pada diri seseorang akan mewujudkan suatu perilaku yang diarahkan pada tujuan mencapai sasaran kepuasan (Gufron, 2012). Menurut Heckhausen, motif sosial adalah motif yang menunjukkan bahwa tujuan yang ingin dicapai mempunyai interaksi dengan orang lain (Ahmadi, 2009).

Menurut Alex Sobur motif dibagi menjadi tiga. Pertama, motif biogenetis, yakni motif-motif yang berasal dari kebutuhan-kebutuhan individu demi kelanjutan kehidupannya secara biologis. Motif biogenetis ini bercorak universal dan kurang terikat dengan lingkungan kebudayaan. Motif biogenetis berada dan berkembang dalam diri individu. Kedua, motif sosiogenetis, yakni motif-motif yang dipelajari individu dan berasal dari lingkungan kebudayaan dimana individu itu berada. Motif sosiogenetis ini tidak berkembang dengan sendirinya tetapi berdasarkan interaksi sosial. Macam motif sosiogenetis banyak sekali dan berbeda-beda sesuai corak kebudayaan di dunia. Ketiga, motif teogenesis, yakni motif yang berasal dari interaksi antara manusia dengan Tuhan, seperti yang terwujud dalam ibadah dan kehidupan sehari-hari dimana individu berusaha merealisasikan norma-norma agamanya. (Sobur, 2003).

\section{TINDAKAN SOSIAL}

Teori tindakan sosial Max Weber berorientasi pada motif dan tujuan pelaku. Dengan menggunakan teori ini kita dapat memahami perilaku setiap individu maupun kelompok. Teori ini bisa digunakan untuk memahami tipe-tipe perilakutindakansetiapindividumaupun kelompok. Dengan memahami perilaku setiap individu maupun kelompok, sama halnya kita telah menghargai dan memahami alasan-alasan mereka dalam melakukan suatu tindakan. Sebagaimana diungkapkan oleh Weber, cara terbaik untuk memahami berbagai kelompok adalah dengan menghargai bentukbentuk tipikal tindakan yang menjadi ciri khasnya sehingga kita dapat memahami alasan-alasan mengapa warga masyarakat tersebut bertindak (Norkholis, 2016).

Aspek pemikiran Weber yang paling terkenal yang mencerminkan tradisi idealis adalah tekanannya pada verstehen (pemahaman subyektif) sebagai metode untuk memperoleh pemahaman yang valid mengenai arti-arti subyektif tindakan sosial. Bagi weber, istilah ini tidak hanya sekedar merupakan introspeksi. Introspeksi bisa memberikan seorang pemahaman akan motifnya 
sendiri atau arti-arti subyektif, tetapi tidak cukup untuk memahami arti-arti subyektif dalam tindakan-tindakan orang lain. Sebaliknya, apa yang diminta adalah empati, kemampuan untuk menempatkan diri dalam kerangka berpikir orang lain yang perilakunya mau dijelaskan dan situasi serta tujuannya mau dilihat menurut perspektif itu. Proses itu menunjuk pada konsep "mengambil peran" yang terdapat dalam interaksionisme simbolik. Tindakan subyek harus dimengerti dalam hubungannya dengan arti subyektif yang terkandung di dalamnya. Untuk itu, orang perlu mengembangkan suatu metode untuk mengetahui arti subyektif ini secara obyektif dan analitis (Pramiyas, 2014).

Weber membedakan empat macam tindakan sosial. Dua tindakan dikategorikan sebagai tindakan rasional dan dua tindakan lainnya dikategorikan sebagai tindakan non-rasional. Dua tindakan yang digolongkan oleh Weber sebagai tindakan rasional adalah zwerk rational (rasionalitas instrumental) dan werkratinonalaction (rasionalitas nilai). Sedangkan affectual action (tindakan afektif) dan traditional action (tindakan tradisional) adalah dua tindakan yang oleh Weber digolongkan sebagai tindakan nonrasional.

Rasionalitas instrumental merupakan tindakan dengan tingkat yang paling tinggi. Hal ini dikarenakan yang menjadi pertimbangan dalam tindakan ini bukan hanya tujuan yang hendak dicapai, melainkan alat yang dipergunakan untuk mencapai tujuan tersebut juga dipertimbangkan. Tujuan dalam rasionalitas instrumental tidak absolut. Tujuan tersebut dapat juga menjadi cara untuk mencapai tujuan berikutnya. Rasionalitas nilai (werkratinonalaction) adalah tipe tindakan kedua yang digolongkan Weber sebagai tindakan rasional. Dalam tindakan ini yang menjadi pertimbangan dari seorang individu adalah hanya sebatas pada caracara yang paling efektif untuk mencapai suatu tujuan. Tujuan yang hendak dicapai telah ada dalam hubungannya dengan nilai-nilai individu yang bersifat absolut. Tujuan tersebut bersifat non-rasional dalam hal dimana seorang individu tidak dapat memperhitungkannya secara objektif mengenai tujuan mana yang harus dipilih. Affectual action (tindakan afektif), adalah suatu bentuk tindakan yang didominasi oleh perasaan atau emosi tanpa adanya refleksi intelektual atau perencanaan yang sadar. Sedangkan tindakan tradisional atau traditional action merupakan suatu tipe tindakan yang didasarkan pada kebiasaan-kebiasaan yang terjadi pada masa lalu. Kedua tipe tindakan yang terakhir ini merupakan tipe tindakan non-rasional, sebab individu yang melakukan tindakantindakan tersebut tidak didasari pada pertimbangan-pertimbangan logis atau berdasarkan pada kriteria rasionalitas yang lain (Legowo, 2012).

\section{METODE PENELITIAN}

Penelitian ini menggunakan metode kualitatif deskriptif, dengan tujuan memberikan gambaran terkait fenomena Ikatan Janda Muslimah Ponorogo (IJMP), dengan mengolah data-data hasil wawancara dan dokumentasi, sehingga mendapat sebuah penjelasan secara lengkap terkait hal tersebut. Selain itu dalam penelitian ini digunakan pendekatan etnometodologi. 
Penelitian kualitatif disebut juga penelitian naturalistik. Disebut kualitatif karena sifat data yang dikumpulkan bercorak kualitatif bukan kuantitatif karenatidakmenggunakanalatpengukur. Disebut naturalistik karena situasi lapangan penelitian bersifat natural atau wajar sebagaimana adanya tanpa dimanipulasi diatur dengan eksperimen atau tes. Pendekatan etnometodologi berupaya untuk memahami, bagaimana masyarakat memandang, menjelaskan dan menggambarkan tata hidup mereka sendiri. Etnometodologi berusaha memahami bagaimana orang-orang mulai melihat, menerangkan, dan menguraikan keteraturan dunia tempat mereka hidup. Seorang peneliti kualitatif yang menerapkan sudut pandang ini berusaha menginterpretasikan kejadian dan peristiwa sosial sesuai dengan sudut pandang dari obyek lainnya (Rahmat, 2009).

Penelitian ini berlokasi atau mengambil setting di Kabupaten Ponorogo, Jawa Timur. Penelitian ini difokuskan pada anggota persaudaraan Ikatan Janda Muslimah Ponorogo (IJMP), hal itu dikarenakan uniknya organisasi ini, mengingat stigma janda yang diidentikkan dengan image negatif. Selain itu organisasi ini sangat menarik karena hanya terdapat di Kabupaten Ponorogo. Informan adalah orang yang memberikan informasi tentang segala hal yang dibutuhkan untuk bahan kajian penelitian tentang anggota organisasi Ikatan Janda Muslimah Ponorogo (IJMP). Teknik yang digunakan untuk memilih atau menentukan informan adalah purposive sampling yang didasarkan atas pertimbangan tertentu dalam memilih sumber.

\section{TEMUAN PENELITIAN}

Komunitas Ikatan Janda Muslimah Ponorogo (IJMP)

Ikatan Janda Muslimah Ponorogo (IMJP) didirikan pada 25 Agustus 1995 di Ponorogo yang bertempat di kediaman Ny. Hj. Suminto Pondok. Peresmiannya dilakukan oleh istri Bupati Ponorogo waktu itu, Ibu Yeti Markum S. Acara peresmian dihadiri oleh calon pengurus sebanyak 19 orang, calon pengurus setiap kecamatan, yaitu kecamatan Ponorogo sebanyak 14 orang, kecamatan Babadan sebanyak 18 orang, Kecamatan Mlarak sebanyak 4 Orang, dan kecamatan Jetis sebanyak 4 orang. Jumlah anggota dan pengurus yang hadir pada awal berdirinya berjumlah 59 orang. Tamu undangan dari kalangan pejabat yang hadir pada waktu peresmian tersebut adalah Bupati Ponorogo, Ketua DPRD Ponorogo, Camat Babadan, Kepala Desa Pondok, serta Danramil Babadan (Munir, 2009).

\section{Motif Menjadi Anggota Ikatan Janda Muslimah Ponorogo (IJMP)}

Beberapa anggota Ikatan Janda Muslimah Ponorogo menuturkan motif khusus mengapa mereka bergabung menjadi anggota di organisasi ini. Sumiatun, salah satu anggota IJMP menuturkan:

Sakjane, iki kulo cerito sekedik nggeh mas. Dadi janda niku mboten penak lo mas. Biasane enten nopo-nopo wonten seng dijagakne, tapi ujug-ujug sembarange pados piambak, kadang rondo niku nggeh dirasani tonggo, nangndi karo sopo, gek nyapo mawon, kadang dadi bahan gunemane uwong-uwong, tapi geh niku sampun dadi resikone urip dadi rondho, sing penting madosi ridhone Gusti 
Allah, InsyaAllah kaleh gusti di paringi dalan (hasil wawancara, 29 Agustus 2016).

(Saya ingin bercerita sedikit ya mas, jadi janda itu tidak menyenangkan. Biasanya ada yang diharapkan, tapi sekarang harus berupaya sendiri, terkadang status janda, jadi bahan gunjingan tetangga, tapi ya sudah jadi resikonya hidup jadi janda, yang penting cari ridho Allah, Insyaallah diberikan jalan sama Allah).

Sementara itu, Sarifah menuturkan:

Lek, alasan khusus kulonggeh mboten wonten, dasare kulo remen lek kumpul-kumpul, nopo meleh kegiatanae positif, dadi kulo nggeh semangat, teng organisasi niki nggeh belajar bareng, diskusi bareng, supoyo pripun she dadi rondo nikuw, seng kuat lan ngerantosi Ridhone Gusti Allah (hasil wawancara, 29 Agustus 2016).

(Alasan khusus tidak ada, pada dasarnya saya suka bersosialisasi, apalagi kalo kegiatannya positif, jadi saya juga bersemangat, di organisasi ini juga kita berlajar bersama, supaya bagaimana menjadi orang yang kuat dan mencari Ridho Allah).

Menurut Murniati salah satu anggota yang lain:

Sebenere nggeh alasan utami kulo nderek organisasi niki, lebih pada pripun saget menyelesaikan persoalan kulo, secara rpibadi, teng masyarakat kulo kan pun rondo, teng mrikikan nggeh saget bertukar pikiran, pengalaman, bab agama, dan juga hubungan kaleh sesame manusia, Insyallah beban e kulo lebih enteng mas (hasil wawancara, 29 Agustus 2016).
(Sebenarnyaalasan utama saya ikutorganisasi ini, lebih pada bagai mana menyelesaikan permasalahan saya, secara pribadi, di masyarakat saya kan udah jadi janda, disini kan bisa menjadi ajang bebrtukar pikiran, pengalaman, terkait persoalan agama, dan juga hubungan sesama manusia, Insyaallah beban saya menjadi ringan).

Ahmad Munir, dalam bukunya Kebangkitan Kaum Janda (2009) menjelaskan bahwa munculnya komunitas janda yang berhimpun dalam Ikatan Janda Muslimah Ponorogo (IJMP) dilatarbelakangi oleh kegelisahan kaum janda terhadap fenomena kaum lemah. Secara historis, pendirian IJMP memang dilatarbelakangi oleh semangat dakwah, yang menyerukan seorang Muslimah untuk menyelamatkan akidah dan kehidupan Muslimah lainnya. Hal ini berarti kegiatan yang dilakukan oleh IJMP tidak semata-mata bersifat kompetitif, yang tidak sehat terhadap kegiatan kelompok lain (Tunjiah, 2010).

Organisasi IJMP ini berasaskan Pancasila dan UUD 1945 dengan tujuan untuk mencari kesejukan dan ketenangan jiwa, agar mampu lebih pasrah kepada Allah dengan mencari ridha-Nya semata. Inilah salah satu slogan yang dituangkan dalam spanduk dalam menyambut sebuah kegiatan IJMP. Slogan ini sebagai gambaran harapan yang dicita-citakan pendiri IJMP, dimana IJMP diharapkan dapat menjadi tempat penemuan naungan kembali bagi para janda yag telah kehilangan suami yang menjadi pelindung semasa hidupnya (Munir, 2009). 
Hasil penelitian lain menunjukkan bahwa persepsi dari para janda membolehkan menikah lagi apabila mampu dalam hal fisik dan lainnya terutama dalam hal lahir dan batin para janda. Penyebab janda menolak untuk menikah karena beberapa faktor, yaitu umur yang sudah tua, lingkungan yang menjadi sorotan, keluarga yang tidak membolehkan menikah, atau anak yang sudah dewasa (Tunjiah, 2010).

Dari beberapa penuturan para anggota IJMP kita bisa melihat bagaimana tindakan sosial yang dilakukan oleh para anggotanya. Dalam statement anggota IJMP bahwa mereka memiliki tujuan dan juga harapan, dan melalui organisasi ini mereka beranggapan bahwa mungkin akan mampu mencapai apa yang dicitacitakan. Sedangkan dalam aspek tindakan rasional memperlihatkan bahwa anggota IJMP dengan bergabung menjadi anggota mereka juga memperlihatkan banyak nilai positif, hal ini dapat terlihat dari slogan yang dimiliki organisasi.

Tindakan sosial yang kedua, tindakan non-rasional, disini kita menemukan alasan yang paling mendasar dimana para anggota IJMP memilih bergabung karena mereka beranggapan bahwa dengan adanya IJMP mereka bisa terbantu secara kelompok dalam berbagai bidang kehidupan, semisal membantu perekonomian melalui usaha-usaha IJMP. Kemudian tindakan non-rasional yang kedua adalah tindakan afektif, bahwa dengan adanya IJMP mereka bisa terwadahi dan tidal lagi merasa minder dalam menjalani kehidupan seharihari. Disinilah mereka mendapatkan pegayoman dengan kultur organisasi yang berangkat dari latar belakang yang sama yaitu status sosial sebagai janda.
Dari pemaparan diatas, dapat diambil sebuah kesimpulan bahwa alasan khusus dari anggota IJMP bergabung menjadi anggota ialah agar bisa menjalin sebuah kekuatan untuk membangun kehidupan yang lebih baik dengan sesama manusia dan juga mencari keridhoan Allah, sehingga mereka bisa bisa tetap menunjukkan eksistensinya dan keluar dari penilaian negatif dari masyarakat. Sementara itu, alasan umum anggota IJMP bergabung menjadi anggota adalah karena dipengaruhi atau didominasi oleh tindakan rasional dan non-rasional yang sangat kuat karena latar belakang janda yang mengharuskan mereka menjalankan kehidupan secara mandiri. Dengan adanya organisasi ini, pada akhirnya akan berkorelasi dengan upaya kelompok ini untuk mewujudkan citacita mereka.

\section{KESIMPULAN}

Organisasi IJMP muncul dan menjadi salah satu kekuatan sosial dan ekonomi bagi para anggotanya dengan cara menggerakkan anggotanya untuk melakukan kegiatan-kegiatan produktif, sehingga anggotanya bisa "survive" dalam menjalani kehidupan di masyarakat. Selain itu, asumsi yang selama ini terbangun akhirnya tidak lagi menghinggapi para anggota kelompok ini sehingga mereka merasa nyaman dalam menjalani kehidupan.

Pilihan untuk bercerai merupakan tindakan sosial yang memiliki makna dan motif tertentu. Dalam penelitian ini ditemukan bahwa kemampuan seorang wanita yang berstatus cerai untuk bertahan hidup, kebutuhan untuk menjadi sosok yang kuat dalam berbagai bidang kehidupan, karena menjadi 
kepala keluarga, dan juga keyakinan terhadap adat dan juga keyakinan agama menjadi motif anggota untuk bergabung dengan IJMP. Mereka bersepakat bahwa tindakan yang mereka pilih memiliki pertimbangan baik rasional dan nonrasional, dan dengan berkelompok mereka mencoba mempertahankan tindakan sosial yang mereka tempuh. Kondisi tersebut memperlihatkan bahwa dengan adanya organisasi Ikatan Janda Muslimah Ponorogo (IJMP), motif pelembagaan organisasi menjadi semakin kokoh. Hal tersebut dianggap sebagai konsekuensi logis untuk mempertanggungjawabkan pilihannya. sehingga mereka berharap dengan adanya organisasi ini akan membentuk kekuatan sosial, ekonomi, politik, serta masa depan mereka.

Kemampuan seorang wanita yang bersatus janda untuk bertahan hidup dan mempengaruhi lingkungan, tidak lepas dari tindakan sosial yang dilatarbelakangi oleh berbagai motif. Munculnya motif tersebut telah menjadi spirit dalam menjalankan organisasi IJMP. Motif itu keberadaannya sangat penting karena hal tersebut bisa menjadi kekuatan yang dapat mendukung kekuatan kolektivitas para janda anggota IJMP.

\section{REKOMENDASI}

Belajar dari pengalaman, organisasi IJMP ini sangat positif, sehingga perlu diperkuat kembali kegiatan-kegiatannya, terutama untuk memperkuat ketahanan para anggotanya dalam berbagai bidang kehidupan baik sosial, ekonomi, budaya, serta keagamaan, sehingga semua anggota kelompok bisa berdaya.

\section{BIBLIOGRAPHY}

Ahmadi, Abu. 2009. Psikologi Sosial. Jakarta: Rineka.

Belsky, Karry. 1990. Psychology of Aging Theory, Research and Interventions. California: Brooks/Cole Publishing Company.

Hendropuspito. 1989. Sosiologi Sistemik. Jakarta: Kaninsius.

Instruksi Presiden RI No. 9, 2000. Tentang Pengarusutamaan Gender dalam Pembangunan Nasional.

Karvistina, Listya. 2011. Persepsi Masyarakat Terhadap Status Janda. Skripsi tidak diterbitkan.

Kephart, Jenny \& Jedlicka. 1991. The Family, Society, and the Individual, 7th Ed. New York: Herper and Row Publishing.

Koentjaraningrat. 1994. Kebudayaan Mentalitas, dan Pembangunan. Jakarta: PT Gramedia Pustaka Utama.

Legowo, Maftuhah \& Martinus. 2012. Pola Preferensi Pendidikan Prasekolah. Paradigma, 2012: 36-37.

Millati, Radhita. 2000. Representasi Janda Dalam Film Indonesia. Skripsi tidak diterbitkan.

Munir, Ahmad. 2009. Kebangkitan Kaum Janda, Akar Teologis-Spiritual Kaum Papa. Yogyakarta: Pustaka Pelajar.

Norkholis, Alis Muhlis. 2016. Analisis Tindakan Sosial Max Weber Dalam Tradisi Pembacaan Kitab Mukhtashar Al-Bukhari. Living Hadis, 2016: 242258.

Pramiyas, Riestifa Chindra. 2014. Tindakan Sosial Ibu Terhadap Anak Pengguna Smartphone Blackberry. Skripsi tidak diterbitkan.

Pusat Bahasa Kamus Besar Bahasa Indonesia. 1997. Jakarta: PT Gramedia Pustaka Utama.

Saharudin. 2001. Nilai Kultur dan Institusi Lokal dalam Konteks Masyarakat Multi 
Etnis, bahan diskusi tidak diterbitkan. Jakarta: Program Pascasarjana, Universitas Indonesia.

Santika, Tika, Nia Hoerniasih \& Een Nurhasanah. 2012. Pemberdayaan Wanita Bagi Tenaga Kerja Wanita (TKW) di Desa Gempol, Kecamatan Jatisari, Kabupaten Karawang. Majalah Ilmiah Unsika, Vol.10, No. 22.

Sobur, Alex. 2003. Psikologi Umum. Bandung: Pustaka Setia.

Soekanto, Sarjono. 1993. Sosiologi Sebagai Pengantar. Jakarta: PT. Raja Grafindo Persada.
Sutopo, Naranda Anggraeni Nova Ayu \& Oksiana Jatiningsih. 2015. Strategi Bertahan Hidup Ibu Tunggal Pedagang Kelas Menengah di Surabaya. Jurnal Kajian Moral Dan Kewarganegaraan, 2015: 286-302.

Syahuti. 2009. Tinjauan Sosiologis Terhadap Konsep Kelembagaan dan Upaya Membangun Rumusan yang Lebih Baik Secara Operasional. Bogor: Pusat Kajian Sosial Ekonomi dan Kebijakan Pertanian.

Tunjiah. 2010. Persepsi Para Janda Di Kelurahan Tonatan Ponorogo Tentang Anjuran Menikah Bagi Janda Dalam Islam. Skripsi tidak diterbitkan. 